\title{
Maize yields and carbon pools in response to poultry litter, rock phosphate and
}

\section{P-solubilizing microorganisms}

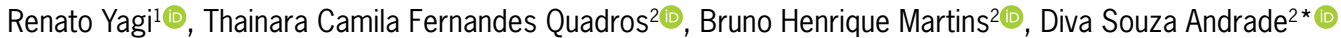

${ }^{1}$ Instituto Agronômico do Paraná - Polo de Pesquisa de Ponta Grossa, Rod. do Café, km 496 - 84001-970 Londrina, PR - Brasil.

${ }^{2}$ Instituto Agronômico do Paraná, Rod. Celso Garcia Cid, km 375 - 86047-902 - Londrina, PR - Brasil.

*Corresponding author <2013divaandrade@gmail.com>

Edited by: Francesco Montemurro

Received April 30, 2018

Accepted October 08, 2018

\begin{abstract}
The acid release of phosphates from rock phosphates (RP) and the retention of ammonium by inorganic phosphates have been studied separately in composting; however, there is a gap in the knowledge of combined application of RP with organic residues and microorganisms. The objectives were to evaluate the combined application of fresh poultry litter (PL) with RP and P-solubilizing microorganisms (M) on soil organic matter pools, microbial biomass $C$ (MB-C) and on whole-plant silage maize and grain yields. Two field experiments tested the effects of timing of applications of PL (8 Mg ha-1), RP (4 Mg ha-1) and microorganisms on soil organic matter pools, nutritional aspects and productive components of maize crop whole-plant silage. A second experiment evaluated the effects of RP doses $\left(0,3,6\right.$ and $\left.9 \mathrm{Mg} \mathrm{ha}^{-1}\right)$ with a fixed dose of PL ( $8 \mathrm{Mg}$ $\mathrm{ha}^{-1}$ ) on maize grains. Application of $\mathrm{PL}+\mathrm{RP}$ decreased soil organic $\mathrm{C}$, while RP alone increased the humin fraction $\mathrm{C}$ compared to the control. The MB-C in soil with $\mathrm{PL}$ and $\mathrm{PL}+\mathrm{RP}+\mathrm{M}$ increased in comparison to the control and the RP. The application of $\mathrm{PL}$, based on an average of fall and spring, increased leaves + stem dry matter, while in the fall on its own, the highest cob yield was observed in the combination of $\mathrm{PL}+\mathrm{RP}$, showing synergistic effects. The best ratio of poultry litter to rock phosphate combination is 2:1 in the anticipated fall application on the maize silage crop or immediate application on the maize grain crops.
\end{abstract}

Keywords: Zea mays, microbial biomass $\mathrm{C}$, organic $\mathrm{C}$, humin fraction $\mathrm{C}$, integrated soil fertility

\section{Introduction}

Estimated global $\mathrm{P}$ reserves suggest future scarcity of phosphate rocks should not be used as a key motivation for an intensification of research (Baveye, 2015). However, increasing global demand for P from the grasslands beyond the croplands (Herrera-Estrella and LópezArredondo, 2016) together with the continual upward trend in the phosphate fertilizer price limit their use and imply there is a need to integrate techniques to achieve P sustainability (George et al., 2016).

Low grade rock phosphates (RP) have been incorporated during the composting process of organic manures, aiming to increase the $\mathrm{P}$ supply (Biswas and Narayanasamy, 2006; Ali et al., 2014; Billah and Bano, 2015) mainly through RP dissolution by acid reactions during decomposition and nitrification processes (Mahimairaja et al., 1995; Biswas and Narayanasamy, 2006). Poultry litter (PL) applied to soil significantly increased nitrifying bacteria activity (Mierzwa-Hersztek et al., 2017). Phosphate-solubilizing microorganisms can also be added to mixtures with RP and organic fertilizers to increase the P supplies (Khan and Sharif, 2012; Abbasi et al., 2013; Abbasi et al., 2015). For example, Pseudomonas, Azospirillum and Agrobacterium inoculated into $\mathrm{RP}$ and poultry manure increased the $\mathrm{P}$ absorption and grain yield in wheat (Abbasi et al., 2013). Phosphate-solubilizing microorganisms can also be added to the composting of RP and manure (Biswas and Narayanasamy, 2006; Khan and Sharif, 2012) to increase the P supplies. Plant growth-promoting rhizobacteria inoculation with poultry litter increased maize growth (Lin et al., 2018).
Brazilian confined poultry production generates large amounts of litter in small areas, and less than $5 \%$ of the nutrient contents have high variability, which limits its use in crops in wider areas due to the cost of transportation (Rogeri et al., 2016). We tested the following hypotheses: 1) could there be synergistic interactions in the soil organic matter pools, the nutritional state and productivity of whole-plant silage maize, when applications of PL and RP, whether or not microorganisms, are added? and 2) is there a maximum dose of RP technical efficiency to apply with PL in response to maize yields. The objective was to evaluate the application of fresh PL with natural RP with P-solubilizing microorganisms on soil organic matter pools and whole-plant silage maize and grain crops.

\section{Materials and Methods}

\section{Description of experiments}

All three field experiments were conducted in a clayey Oxisol classified as Rhodic Haploperox (Soil Survey Staff, 2014) in the Ponta Grossa municipality $\left(25^{\circ} 05^{\prime} 42^{\prime \prime}\right.$ S; 5009'43" W; $969 \mathrm{~m}$ a.s.1.), in the state of Paraná, Brazil. The site has a humid subtropical climate with mild summers, $\mathrm{Cfb}$ climate, and evenly distributed rainfall ranging from 1,100 to $2,000 \mathrm{~mm}$, no dry season and the mean temperature of the warmest month does not reach $22^{\circ} \mathrm{C}$ with frequent frosts occur annually with a mean 10- to 25-day extension period (Alvares et al., 2013).

The soil area presented undulating relief varying from flat to mild, with less than a $6 \%$ slope, that had been cultivated in a no-tillage system for approximately 
30 years, involving successions/rotations of maize (Zea mays L.), soybean (Glycine $\max$ (L.) Merrill), common bean (Phaseolus vulgaris L.), black oats (Avena strigosa Schreb.) and wheat (Triticum aestivum L.). Soil samples were physically characterized (EMBRAPA, 1997) at depths of 0 to $0.1 \mathrm{~m}$ and 0.1 to $0.2 \mathrm{~m}$ and contained, respectively, 347 and $340 \mathrm{~g} \mathrm{~kg}^{-1}$ clay, 346 and $414 \mathrm{~g} \mathrm{~kg}^{-1}$ silt and 307 and $247 \mathrm{~g} \mathrm{~kg}^{-1}$ sand. Soil chemical analyses were also performed by extracting $\mathrm{P}$ and $\mathrm{K}$ using the Mehlich1 method, the $\mathrm{pH}\left(1: 2.5\right.$; soil: $\left.0.01 \mathrm{~mol} \mathrm{~L}^{-1} \mathrm{CaCl}_{2}\right)$, $\mathrm{Ca}^{2+}$ and $\mathrm{Mg}^{2+}$ using $\mathrm{KCl}\left(1 \mathrm{~mol} \mathrm{~L}^{-1}\right)$ and $\mathrm{H}+\mathrm{Al}$ using the SMP buffer solution (Pavan et al., 1992) and the organic $\mathrm{C}$ using the Walkley-Black method (Walkley and Black, 1934). In soil layers of 0 to $0.1 \mathrm{~m}$ and 0.1 to $0.2 \mathrm{~m}$, the results were, respectively, 6.4 and $4.1 \mathrm{mg} \mathrm{dm}^{-3} \mathrm{P}, 27.4$ and $25.3 \mathrm{~g} \mathrm{dm}^{-3} \mathrm{C}, 5.5$ and $5.5 \mathrm{pH}, 0.41$ and $0.19 \mathrm{cmol}_{\mathrm{c}}$ $\mathrm{dm}^{-3} \mathrm{~K}^{+}, 6.2$ and $5.4 \mathrm{cmol}_{\mathrm{c}} \mathrm{dm}^{-3} \mathrm{Ca}^{2+}, 3.6$ and $3.2 \mathrm{cmol}_{\mathrm{c}}^{\mathrm{c}}$ $\mathrm{dm}^{-3} \mathrm{Mg}^{2+}, 5.0$ and $5.3 \mathrm{cmol}_{\mathrm{c}} \mathrm{dm}^{-3}$ of $\mathrm{H}^{+}+\mathrm{Al}^{3+}$ and $75 \%$ and $73 \%$ of base saturation index (BSI).

\section{Interaction of $\mathbf{P L}+\mathbf{R P}+\mathbf{M}$ application}

To evaluate if there is a synergistic effect on maize silage crop due to $\mathrm{PL}$ with the application of $\mathrm{RP}$, with or without phosphate-solubilizing microorganisms, two field experiments of maize silage crops were carried out in adjacent and uniform areas. Each experimental plot consisted of four rows with spacing of $0.8 \mathrm{~m}$ apart and 7 $\mathrm{m}$ long $\left(22.4 \mathrm{~m}^{2}\right)$. Seeds of maize triple hybrid (AG5011) were sowed with a density of 55,000 plants ha $^{-1}$. Five treatments were established during late May (fall) and early Oct (spring), during the initial phase (ten days after emergence) and after cultivation of black oats cV IPR 61 , spaced $0.17 \mathrm{~m}$ apart with a sowing density of $40 \mathrm{~kg}$ $\mathrm{ha}^{-1}$ seeds. The cumulative precipitation data and average minimum and maximum temperatures during the experimental period, fall and spring, are presented biweekly in Figure 1A.

\section{Experimental design and treatments}

In both experiments of application times that included fall and spring, treatments were arranged in a randomized complete block design with five replications. The following five treatments were evaluated: 1) control without fertilizers; 2) $8 \mathrm{Mg} \mathrm{ha}^{-1}$ of poultry litter (PL); 3) 4 $\mathrm{Mg} \mathrm{ha}^{-1}$ of Alvorada rock phosphate (RP); 4) $8 \mathrm{Mg} \mathrm{ha}^{-1}$ of $\mathrm{PL}$ mixed with $4 \mathrm{Mg} \mathrm{ha}^{-1}$ of RP $(\mathrm{PL}+\mathrm{RP})$; and 5) $\mathrm{PL}+\mathrm{RP}$ and phosphate-solubilizing microorganisms $(\mathrm{PL}+\mathrm{RP}+\mathrm{M})$. The quantities of inputs applied were determined according to the amounts usually applied by smallholders in the south-central region of Paraná, Brazil, and in total theoretical quantities of $\mathrm{N}$ and $\mathrm{P}$ required for black oat and whole-plant maize silage. The PL data from the characterization showed $16 \%$ of moisture, 28.2 of $\mathrm{C}, 25.2$ of $\mathrm{N}$, 11.8 of $\mathrm{P}, 33.7$ of $\mathrm{K}, 48.1$ of $\mathrm{Ca}$, and 17.8 of $\mathrm{Mg}$ (in $\mathrm{g} \mathrm{kg}^{-1}$ ) and 732.6 of $\mathrm{Cu}, 721.8$ of $\mathrm{Zn}, 54.8$ of $\mathrm{B}$ and 770.9 of $\mathrm{Mn}$ (in $\mathrm{mg} \mathrm{kg}^{-1}$ ). The Alvorada RP used contained $240 \mathrm{~g} \mathrm{~kg}^{-1}$ of total $\mathrm{P}_{2} \mathrm{O}_{5}, 32 \mathrm{~g} \mathrm{~kg}^{-1}$ of $\mathrm{P}_{2} \mathrm{O}_{5}$ in citrate + water and $77 \mathrm{~g}$ $\mathrm{kg}^{-1}$ of soluble in citric acid (Foloni et al., 2008).

\section{Inocula preparation and sowing}

To inoculate the $\mathrm{RP}+\mathrm{PL}$, microorganisms that could solubilize calcium phosphate in culture medium were chosen based on previous studies and included Rhizobium sp. (IPR1539) isolated from common bean nodules, the fungus Talaromyces sayulitensis (IPR6005) isolated from oil shale by-products (de Goes et al., 2017) and cyanobacteria (IPR7120) from a photosynthetic pond. Next, they were grown in specific media, for Rhizobium sp. Yeast Mannitol-YM (Vincent, 1970), for T. sayulitensis (fungus) Saboroud-AS agar (Silva et al., 2004) and for cyanobacteria BG11 (Rippka et al., 1979). Each microbial suspension was mixed using a 1:1:1 ratio to compose the inoculum. The treatments with $\mathrm{PL}+\mathrm{RP}$ and $\mathrm{PL}+\mathrm{RP}+\mathrm{M}$ were prepared approximately ten days before their applications in the field, and the water content was standardized in all of the treatments according to the inoculant solution volume in the latter treatment. The inoculant was applied to the PL + RP mixture using $750 \mathrm{~mL}$ of nutrient solution and periodic stirring for homogenization, and after ten days of reaction, all of the treatments were broadcast on the surface of the respective plots in both seasons. Subsequently, a black oat crop was desiccated with glyphosate at $2.5 \mathrm{~L} \mathrm{ha}^{-1}$, a whole maize silage crop (cultivar AG5011) was sown with 0.85 $\mathrm{m}$ between rows and density of 55,000 plants ha ${ }^{-1}$ after thinning.

\section{Response of maize grain yields to RP with $\mathrm{PL}$}

To evaluate the mixture of $\mathrm{RP}+\mathrm{PL}$, an experiment was carried out in sand-loam in the Ponta Grossa munic-

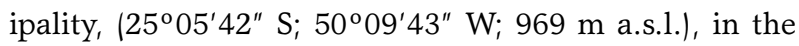
state of Paraná, Brazil, between Oct 2016 and May 2017. The weather conditions during the study are shown in Figure 1B. The relief in the soil area was flat with approximately less than a $3 \%$ slope and had been cultivated in a no-tillage system for approximately 10 years with maize (Zea mays L.), soybean (Glycine max (L.) Merrill) and black oats (Avena strigosa Schreb.). Soil samples (0 to $0.2 \mathrm{~m}$ ) were physically (EMBRAPA, 1997) and chemically (Pavan et al., 1992) characterized, resulting in the following: $27.1 \mathrm{mg} \mathrm{dm}^{-3}$ of $\mathrm{P}, 14.6 \mathrm{~g} \mathrm{dm}^{-3}$ of $\mathrm{C}, 5.1$ of $\mathrm{pH}$, $0.12 \mathrm{cmol} \mathrm{dm}^{-3}$ of $\mathrm{K}, 2.1 \mathrm{cmol} \mathrm{dm}^{-3}$ of $\mathrm{Ca}, 0.9 \mathrm{cmol}_{\mathrm{c}}$ $\mathrm{dm}^{-3}$ of $\mathrm{Mg}, 4.3 \mathrm{cmol}^{3}$ of $\mathrm{H}+\mathrm{Al}$ and $43 \%$ of the base saturation index (BSI). The experiment was implement-

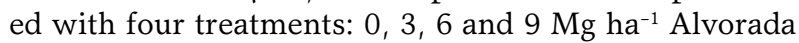
$\mathrm{RP}$ doses mixed with $8 \mathrm{Mg} \mathrm{ha}^{-1}$ of PL in a randomized block design and four repetitions. For this experiment, both RP and PL were the same as those used in the two experiments with the whole plant silage maize and were prepared under the same conditions. After preparation, the treatments were applied uniformly in each plot 10 days before sowing. Each plot of $3.6 \mathrm{~m}$ x $7.0 \mathrm{~m}\left(25.2 \mathrm{~m}^{2}\right)$ consisted of four lines of simple hybrid maize (DKB 390) that were spaced $0.9 \mathrm{~m}$ apart with a density of 55,000 plants ha ${ }^{-1}$. Thirty plants from the two central lines of each plot were harvested, to estimate cob lengths, numbers of rows per cob and grain yields at $13 \%$ moisture. 

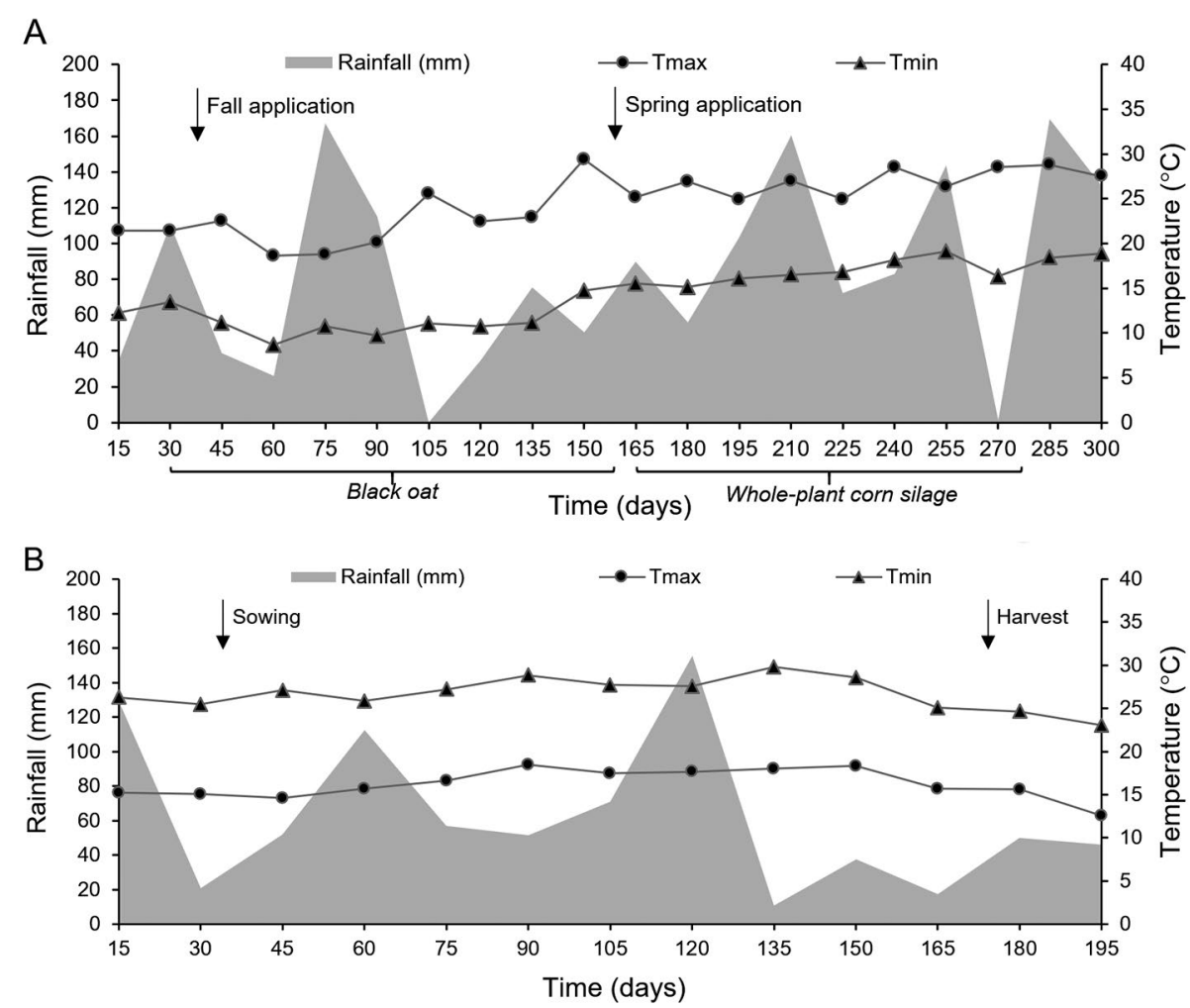

Figure 1 - Rainfall and maximum $\left(T_{\max }\right)$ and minimum $\left(T_{\min }\right)$ temperatures during experimental periods $\left.A\right)$ in experiments of poultry litter, rock phosphate and microorganisms were jointly applied to maize silage crop in the fall and the spring, B) in experiment of doses of rock phosphate with poultry litter on maize grain yields.

\section{Plant sampling, nutrients and yields analyses}

In order to evaluate the nutritional status of maize silage, samples from diagnostic leaves on the cob base were collected from two central lines of each plot at the $\mathrm{R} 1$ stage, when more than half of the plants were in the tasseling period. N, P and $\mathrm{K}$ contents were determined as described previously by Miyazawa et al. (2009) using digestion with sulfuric acid and hydrogen peroxide with ammonium-N by the UV-visible spectrophotometry method and nitric perchloric acid digestion, the determination of $\mathrm{P}$ using the molybdenum blue spectrophotometric method and $\mathrm{K}$ by flame photometry. For estimating the maize silage yield component, ten plants from the two central lines were harvested per plot. The plants were segmented into leaves + stem and cobs with straw, and, subsequently, fresh maize matter total yields were calculated for the whole maize plant silage. Plant samples were weighed, crushed and subsampled to determine dry matter yield in the whole maize plant silage and cobs.

\section{Chemical carbon pool and $\mathrm{C}$ microbial biomass analyses}

In the experiment where the treatments were applied to the black oat crop in the fall, soil samples 10 to $0.1 \mathrm{~m}$ depth) were collected with a tube soil probe from nine points in each plot to comprise a compost sample per plot. The samples were split into two subsamples for chemical carbon pool and $\mathrm{C}$ microbial biomass analyses. For chemical $\mathrm{C}$ analyses, soil subsamples were dried in an oven with forced air circulation at $60^{\circ} \mathrm{C}$ and extracted, and the humic substances were fractionated using $\mathrm{NaOH}$ dissolution, the separation of alkaline-soluble fractions (C-HS) with sulfuric acid and the determination of $\mathrm{C}$ in humic acid (C-HA), fulvic acid (C-FA) and humin $(\mathrm{C}-\mathrm{H})$ fractions using the Walkley-Black method with modifications (Swift, 1996). Microbial biomass C (MB-C) was determined in fresh subsamples that were kept at $4{ }^{\circ} \mathrm{C}$ by the fumigation-extraction method as described by Vance et al. (1987) with a correction factor (kc) of 0.33 , and the results were corrected to dry soil.

\section{Statistical analyses}

The results were submitted to an analysis of variance $\mathrm{F}$ test at $p<0.05$, considering joint analysis of the experiments, and the means from dependent variables were compared using Student's t-test $(p<0.05)$ from the finding of the relationships between the average square residuals of the experiments that were inferior to $7: 1$. Pearson linear correlation analyses $(p<0.05)$ were constructed between macronutrients in maize diagnostic leaf in both the fall and spring seasons and soil organic $\mathrm{C}$ pools. The results of RP doses were evaluated by polynomial regression analysis at $p<0.05$ and $p<0.01$. 


\section{Results and Discussion}

\section{Times of application of $P L+R P+M$ to the maize silage crop}

The soil organic $\mathrm{C}$ levels did not change as a function of $\mathrm{PL}+\mathrm{RP}$ with $\mathrm{P}$-solubilizing microorganisms $(\mathrm{PL}+\mathrm{RP}+\mathrm{M})$ application or of PL or RP alone. However, the application of these inputs combined $(\mathrm{PR}+\mathrm{RP})$ resulted in significant reduction compared to the average of other treatments and to the control (Figure 2A).

The C-FA, $36 \%$ of the extracted humic substances did not vary in any of the treatments, while for the C-HA that represented $64 \%$ of the humic substances, application of $\mathrm{PL}+\mathrm{RP}+\mathrm{M}$ decreased significant levels compared to the control by $23 \%$ and the PL by $21 \%$ (Figure 2B). The $\mathrm{C}-\mathrm{H}$ contained $75 \%$ of the humic substances fractions and increased $13 \%$ with the RP application compared to the control in contrast to the other treatments that contained $\mathrm{PL}(\mathrm{PL}, \mathrm{PL}+\mathrm{RP}$ and $\mathrm{PL}+\mathrm{RP}+\mathrm{M})$ (Figure 2C).

The treatments involving poultry litter $(\mathrm{PL}$ and $\mathrm{PL}+\mathrm{RP}+\mathrm{M}$ ) increased the MB-C contents by $24 \%$ and $18 \%$ compared to the control and RP treatments, respectively, with no differences between them (Figure 2D). The isolated application of PL resulted in $20 \%$ more $M B-C$ in relation to the isolated application of $\mathrm{RP}$, although the joint application of these inputs $(\mathrm{PL}+\mathrm{RP}) \mathrm{did}$ not differ from RP treatment. As a counterpart to this, fluoride release from acid dissolution of RP by organic acids may have inhibited microbial growth and metabolism (Mendes et al., 2013), while the contribution of exogenous microorganisms $(\mathrm{PL}+\mathrm{RP}+\mathrm{M})$ may have mitigated this toxic effect in the MB-C. These effects could also be associated with poultry microbial characteristics, for example, the microbial biomass (carbon and phosphorus) in simple poultry litter compost had an increase higher than poultry litter + RP after 45 days of composting (Billah and Bano, 2015). Likewise, microbial biomass was higher in soils with poultry litter biochar applied (Mierzwa-Hersztek et al., 2017). It has also been suggested that $\mathrm{P}$ solubilizing bacteria and poultry manure accelerated the dissolution/solubilization of rock phosphate, improving its capacity to release $\mathrm{P}$ for crops (Abbasi and Manzoor, 2018).

The fresh matter yields of the whole-plant maize silage did not change with the fall PL application, whether rock phosphate $(\mathrm{PL}+\mathrm{RP})$ and $\mathrm{P}$-solubilizing microorganisms $(\mathrm{PL}+\mathrm{RP}+\mathrm{M})$ were added or not (Figure $3 \mathrm{~A})$. However, the isolated RP application in the fall decreased fresh matter yields by $15 \%$ and $13 \%$ in relation to the PL and PL + RP applications, respectively, and by $14 \%$ in comparison to the RP spring application.

There was no difference between fresh matter yields from the treatments (including the control) when applied immediately before maize sowing in the spring (Figure 3A).

For the dry yields of leaves + stems, means of fall and spring, there was an average significant increase with the PL alone regardless of the season application (Figure 3B). The RP application, alone or with PL $(\mathrm{PL}+\mathrm{RP})$ or with $\mathrm{PL}$ and phosphate-solubilizing microorganisms $(\mathrm{PL}+\mathrm{RP}+\mathrm{M})$ did not yield any significant differences compared to the control (Figure 3B).

There was an interaction between the treatments and their application times on the dry matter yields of the cobs (Figure 3C). In the spring season application, there
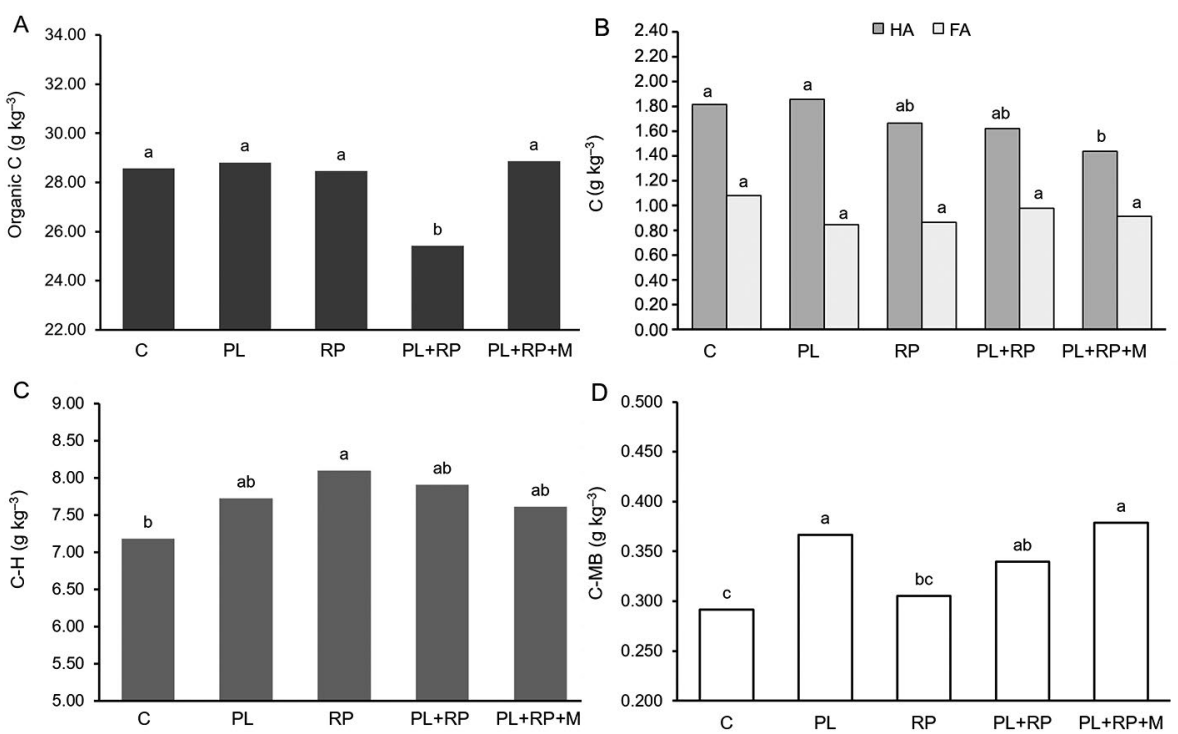

Figure 2 - Organic carbon A), $C$ in humic (HA) and $C$ in fulvic (FA) fractions $B$ ), $C$ in humin (C-H) fraction $C$ ) and $C$ in microbial biomass (C-MB) D) in soil with poultry litter $(\mathrm{PL})$, rock phosphate $(\mathrm{RP})$ and $\mathrm{P}$-solubilizing microorganisms $(\mathrm{M})$ applied in the fall. Same letters in each dependent variable indicate difference $(p<0.05)$ by Student's t-test. 

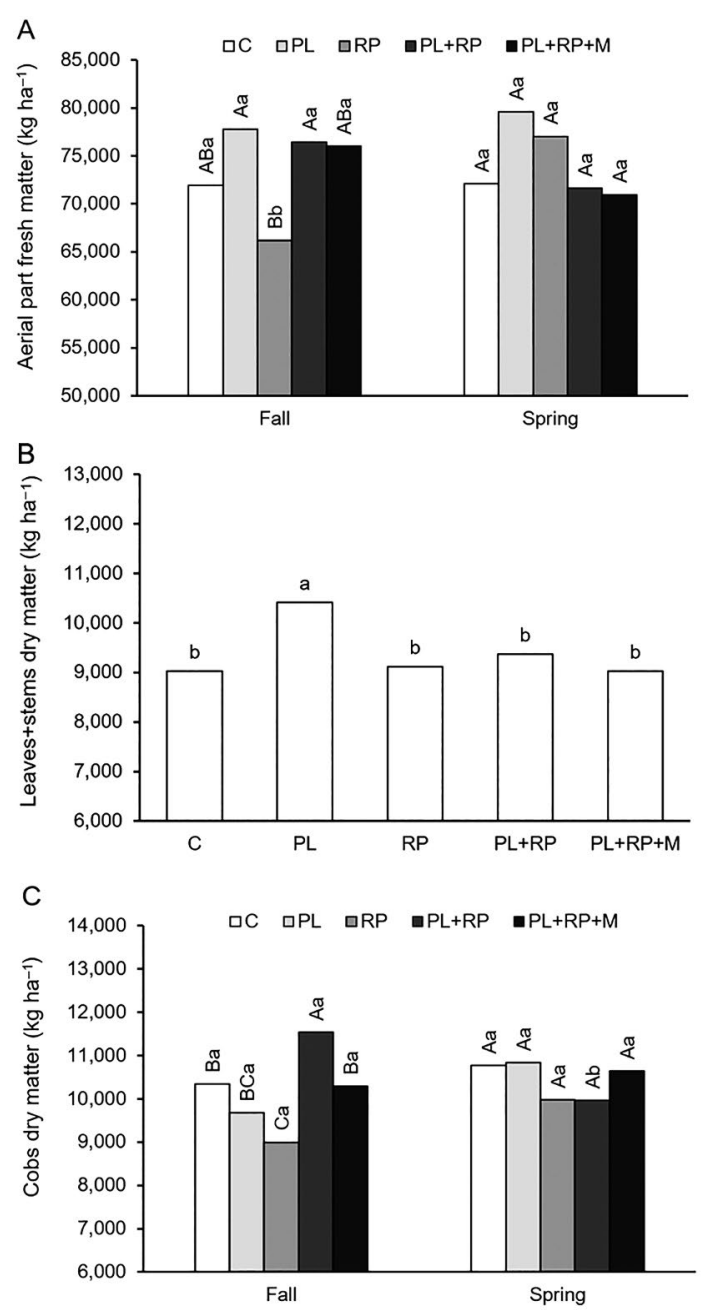

Figure 3 - Effect of poultry litter (PL), rock phosphate (RP) and P-solubilizing microorganisms (M) applied to the soil in the fall and spring on maize silage A) aerial part fresh matter of wholeplant maize silage, B) leaves + stems dry matter yield, values are means of fall and spring and C) cob dry matter yields. Same letters in each dependent variable, uppercase between treatments in each season and lower case between seasons in each treatment, indicate difference $(p<0.05)$ by Student's t-test

were no differences between the treatments in the dry matter yields of the cobs. In the fall treatment applications, PL + RP increased the cob dry matter yields by $12 \%$ compared to the C, $20 \%$ compared to the PL, $28 \%$ compared to the RP and $12 \%$ compared to the $\mathrm{PL}+\mathrm{RP}+\mathrm{M}$. The fall application of PL+RP increased $16 \%$ compared to the spring application of these treatments.

There were effects due to the fall applications of $\mathrm{PL}+\mathrm{RP}$ applied that may be related to the decrease in soil organic C levels (Figure 2A) and the increase in cob dry matter maize yields (Figure 3C). These results confirm our hypothesis that combined application of $\mathrm{PL}+\mathrm{RP}$ has synergistic effects on both soil organic pools and productivity components of the whole-plant silage maize crop according to the application time. Furthermore, for the fall application, there was an increase in MB-C contents with both PL alone and combined with $\mathrm{RP}$ and microorganisms $(\mathrm{PL}+\mathrm{RP}+\mathrm{M})$ when compared with control and $\mathrm{RP}$, which suggests that a positive priming effect from PL may have occurred, which most likely improved microbial growth (Figure 2D). In soils with poultry litter biochar added, microbial biomass was significantly greater than in soils with mineral fertilizer applied (Mierzwa-Hersztek et al., 2017). The main justification for the RP with fresh PL mixture (Abbasi et al., 2013) or RP incorporation in the composting process (Biswas and Narayanasamy, 2006; Ali et al., 2014; Billah and Bano, 2015) is the proton release during fertilizer decomposition and ammonium nitrification. The high concentrations of $\mathrm{Ca}$ and $\mathrm{P}$ available in the PL in addition to the organic acid and proton neutralization by $\mathrm{CaCO}_{3}$ present in the organic fertilizer hamper the dissolution of RP (Mahimairaja et al., 1995). In our study, $769 \mathrm{~kg} \mathrm{ha}^{-1}$ of $\mathrm{CaCO}_{3}$ and $216 \mathrm{~kg} \mathrm{ha}^{-1}$ of $\mathrm{P}_{2} \mathrm{O}_{5}$ in $8 \mathrm{Mg}$ $\mathrm{ha}^{-1}$ of PL were applied to the soil with low $\mathrm{P}$ and very high Ca levels in the first $0.1 \mathrm{~m}$. However, plant roots enhance the RP dissolution using the supply of protons and organic acids and decrease the activity of the dissolution products $\mathrm{P}$ and especially $\mathrm{Ca}$ by plant uptake (Bolan et al., 1997). Plant root growth can exude organic substances that indirectly form symbioses with rhizosphere microorganisms, increasing microbial turnover and soil organic matter decomposition that result in the decreasing of soil organic $\mathrm{C}$ (Figure $2 \mathrm{C}$ ), which may become nutrients available to increase cob dry matter maize yields (Figure 3C).

In the process of composting poultry manure, it is estimated that if all the $\mathrm{H}^{+}$from organic acids and ammonium nitrification aided in the RP dissolution, approximately $86 \%$ to $100 \%$ of the P would be released (Mahimairaja et al., 1995). In addition, ammonium-N released with the native soil organic matter decomposition and present in the added poultry litter may have been retained in the soil with the formation of ammonium phosphates.

With the fall PL application, on average $88 \%$ of the $\mathrm{N}$ is mineralized, and $72 \%$ of this mineralized amount is lost primarily by nitrate leaching (Feng et al., 2015). The amounts of mineralized N with PL applications in the fall and spring are similar, averaging $54 \%$, but $\mathrm{N}$ losses are higher in the fall than in the spring due to the leaching and denitrification processes, respectively, indicating that the spring is the best time to apply $\mathrm{PL}$ to the maize crop (Feng et al., 2015).

The PL and RP interaction effects were not detected by changes in the $\mathrm{P}$ and $\mathrm{N}$ concentrations in maize diagnostic leaves (Table 1), suggesting that there was greater efficiency in fresh shoot matter production and the dry matter of leaves + stems and cobs with the application of PL + RP (Figure 1). Giro et al. (2016) reported increases in the dry matter of maize shoot and roots without, however, increasing $\mathrm{P}$ concentrations in both, 
Table 1 - Nitrogen, phosphorus and potassium contents in diagnostic leaves of the whole- plant maize crop and Pearson correlation coefficients $(p<0.05)$ between foliar nutrients and total organic $\mathrm{C}$ and in the fractions of humic acids (C-AH), fulvic acids (C-AF), humin (C-H), humic substances (C-SH), and microbial biomass (MB-C).

\begin{tabular}{|c|c|c|c|c|c|c|}
\hline \multirow{3}{*}{ Treatments } & \multicolumn{6}{|c|}{ Experiments } \\
\hline & \multicolumn{3}{|c|}{ Fall } & \multicolumn{3}{|c|}{ Spring } \\
\hline & $\mathrm{N}$ & $\mathrm{P}$ & K & $\mathrm{N}$ & $P$ & K \\
\hline & & & - $\mathrm{mg}$ & $\mathrm{g}^{-1}$ & & \\
\hline C & $22.6^{\mathrm{Aa}}$ & $3.6^{\mathrm{Aa}}$ & $19.8^{\mathrm{Aa}}$ & $23.8^{\mathrm{Aa}}$ & $3.5^{\mathrm{Aa}}$ & $20.6^{\mathrm{Aa}}$ \\
\hline PL & $22.7^{\mathrm{Aa}}$ & $3.4^{\mathrm{Aa}}$ & $19.4^{\mathrm{Aa}}$ & $22.6^{\mathrm{Aa}}$ & $3.6^{\mathrm{Aa}}$ & $20.5^{\mathrm{Aa}}$ \\
\hline $\mathrm{RP}$ & $22.5^{\mathrm{Aa}}$ & $3.4^{\mathrm{Aa}}$ & $18.8^{\mathrm{Aa}}$ & $25.4^{\mathrm{Aa}}$ & $3.6^{\mathrm{Aa}}$ & $20.0^{\mathrm{Aa}}$ \\
\hline $\mathrm{PL}+\mathrm{RP}$ & $22.6^{\mathrm{Aa}}$ & $3.5^{\mathrm{Aa}}$ & $19.2^{\mathrm{Aa}}$ & $23.5^{\mathrm{Aa}}$ & $3.7^{\mathrm{Aa}}$ & $20.8^{\mathrm{Aa}}$ \\
\hline \multirow[t]{2}{*}{$\underline{\mathrm{PL}+\mathrm{RP}+\mathrm{M}}$} & $21.0^{\mathrm{Aa}}$ & $3.5^{\text {Аa }}$ & $19.0^{\mathrm{Ab}}$ & $23.5^{\mathrm{Aa}}$ & $3.7^{\mathrm{Aa}}$ & $20.7^{\text {Аa }}$ \\
\hline & \multicolumn{6}{|c|}{ Pearson correlation coefficients } \\
\hline Organic C & $0.00^{\text {ns }}$ & $-0.15^{\text {ns }}$ & $-0.07^{\mathrm{ns}}$ & $0.04^{\text {ns }}$ & $-0.21^{\text {ns }}$ & $-0.15^{\text {ns }}$ \\
\hline C-AH & $0.02^{\text {ns }}$ & $0.17^{\text {ns }}$ & $0.31^{\text {ns }}$ & $-0.13^{\text {ns }}$ & $-0.27^{\text {ns }}$ & $0.08^{\text {ns }}$ \\
\hline C-AF & $0.12^{\text {ns }}$ & $-0.16^{\text {ns }}$ & $0.11^{\mathrm{ns}}$ & $0.09^{\text {ns }}$ & $-0.12^{\text {ns }}$ & $-0.06^{\text {ns }}$ \\
\hline $\mathrm{C}-\mathrm{H}$ & $0.46^{*}$ & $-0.27^{\mathrm{ns}}$ & $0.31^{\text {ns }}$ & $-0.13^{\text {ns }}$ & $-0.27^{\text {ns }}$ & $0.08^{\text {ns }}$ \\
\hline C-HS & $0.51^{*}$ & $-0.26^{\text {ns }}$ & $-0.17^{\text {ns }}$ & $-0.16^{\text {ns }}$ & $-0.21^{\text {ns }}$ & $-0.30^{\text {ns }}$ \\
\hline MB-C & $-0.16^{\text {ns }}$ & $0.11^{\text {ns }}$ & $-0.03^{\text {ns }}$ & $-0.17^{\text {ns }}$ & $0.15^{\text {ns }}$ & $0.16^{\text {ns }}$ \\
\hline
\end{tabular}

$\mathrm{C}=$ control; $\mathrm{PL}=$ poultry litter; $\mathrm{RP}=$ rock phosphate; $\mathrm{M}=\mathrm{P}$-solubilizing microorganisms; ns = no significant; ${ }^{*} p<0.05$; Values are means of four replicates and when followed by the same letter, lowercase comparing season within of each line and uppercase within of each column, do not differ by Student's t-test $(\alpha=0.05)$.

indicating that there was an increase in the efficiency of $\mathrm{P}$ use by maize plants. However, the hypothesis that the joint application of these inputs promoted the retention of $\mathrm{N}$ in the organo-mineral complex of the soil is corroborated by the correlations of this nutrient with the $\mathrm{C}-\mathrm{HS}$ and $\mathrm{C}-\mathrm{H}$ contents (Table 1). Ammonium retention in high cation exchange capacity in both humin and humic substances can decrease the losses of $\mathrm{N}$ by ammonia volatilization and increase the soil nitrate contents and dry matter of maize plants (Ahmed et al., 2012).

On the other hand, no decrease in soil organic C content or changes in any component yields of wholeplant maize silage with $\mathrm{PL}+\mathrm{RP}+\mathrm{M}$ can be attributed to the toxicity effect caused by the release of fluorine from PR by P-solubilizing microorganisms. For maize, the inoculation of a mixture of species of Pseudomonas, Bacillus, Lysinibacillus, Paenibacillluspeoriae did not change plant biomass production (Lin et al., 2018).

Fluorine released from the RP decreases fungal growth, citric acid production, the acidification conditions and P solubilization (Mendes et al., 2013) and, consequently, prevents the priming effect that occurs in the organic $\mathrm{C}$ soil contents, ammonium phosphate formation and increases the whole-plant maize silage yield components (Figure 1C). Although the $\mathrm{PL}+\mathrm{RP}+\mathrm{M}$ application did not lead to a decrease in soil organic $\mathrm{C}$ levels, the decrease in C-HA levels in this treatment compared to the control indicated that there may also have been other positive priming effects. Lower $\mathrm{K}$ contents in the maize diagnostic leaves following a fall application of $\mathrm{PL}+\mathrm{RP}+\mathrm{M}$ (Table 1) may reflect the lower adsorption sites with lower levels of C-HA in the soil surface layer in this same treatment (Figure 2B).

In comparison with the control treatment, the $\mathrm{C}-\mathrm{H}$ content increase with the RP application (Figure 2C) may be related to alkali-soluble humic substance sorption increase by ligand-exchange mechanism in response to positive charge development in mineral surfaces (Murphy et al., 1990). With the apatite dissolution in acid conditions, positive charge occurrence in mineral surfaces appear due to the chemisorption of protons and other cations (Dorozhkin, 1997). Consequently, the potential alkali-soluble humic substance adsorption to the colloidal complex and/or the released fluorine toxic effect due to the early application of RP on maize crop may justify the decrease in whole-plant maize silage fresh matter productivity (Figure 3A). In addition, the $\mathrm{C}-\mathrm{H}$ content increase with $\mathrm{PL}+\mathrm{RP}(10 \%)$ or with $\mathrm{PL}+\mathrm{RP}+\mathrm{M}(6 \%)$ compared to the control was not relevant $(p>0.05)$, possibly due to the positive priming effects caused by the roots in the soil aggregate disruption and in the microbial activation caused by easily available substance releases (Kuzyakov, 2002). This justification is collaborated by the increase in the MB-C contents when compared to the control by $17 \%$ with the addition of PL + RP and by $24 \%$ with $\mathrm{PL}+\mathrm{RP}+\mathrm{M}$ (Figure $2 \mathrm{D}$ ) attributed to inorganic phosphorus solubilized by microorganisms (Billah and Bano, 2015), which in turn may also justify the decrease in the observed $\mathrm{C}-\mathrm{AH}$ levels with $\mathrm{PL}+\mathrm{RP}+\mathrm{M}$ (Figure $2 \mathrm{~B})$. In the fall, the highest cob yields were achieved with the combination of $\mathrm{PL}+\mathrm{RP}$ applied in a ratio of $2: 1$ (Figure 3C). The use of organic residues on agricultural soil can be an alternative for organic production for oat biomass nutrition, maize grain yield (Panchoni et al., 2016) and wheat nutrition (Kuwano et al., 2016).

Although there was no difference between the times of the application of PL on the dry matter yields of the leaves + stems (data not shown) the increase with the organic fertilizer application in relation to the control was almost twofold higher in the fall than in the spring. These results are in contrast with those obtained by Tewolde et al. (2013) who obtained this in only one year, within three years of application of $9 \mathrm{Mg} \mathrm{ha}^{-1} \mathrm{PL}$, there were larger maize grain yields in the spring compared to the fall application. However, these authors observed an average $17 \%(p<0.05)$ grain yield decrease during the period examined with the anticipated PL application in the fall compared to the spring, which was justified by Feng et al. (2015) due to the $\mathrm{N}$ losses by leaching in silty clay loam soil.

The $\mathrm{N}$ and $\mathrm{P}$ contents in the maize diagnostic leaves did not vary according to the treatments and their applications in the fall or the spring (Table 1). In relation to non-composted animal manures, RP was also applied to poultry, cattle and swine manures and invariably increased the plant $\mathrm{P}$ concentration and yields in horticultural crops in Africa (Sanni and Ewulo, 2015; Agyarko et al., 2016) and Asia (Abbasi et al., 2015). 
The levels of $\mathrm{K}$ exhibited the same trend, except that the application of $\mathrm{PL}+\mathrm{RP}+\mathrm{M}$ in the spring increased the content of $\mathrm{K}$ by $9 \%$ compared to the application of this treatment in the fall. The leaf $\mathrm{N}$ levels in the maize silage were correlated $(p<0.05)$ with $\mathrm{C}-\mathrm{HS}(\mathrm{r}=0.51, p$ $<0.05)$ and $\mathrm{CH}(\mathrm{r}=0.46, p<0.05)$ when the treatments were applied in the fall but not in the spring (Table 1).

Response of maize grain yields to RP doses with PL

Maize grain yields were evaluated to determine if the effect of the application of PL and RP was dependent on the dose and proportion of the RP. This study was complementary to the previous one, since it identified the interaction between the applications of PL and RP in the fall on the dry matter yields of cobs in wholeplant silage maize crops. A linear decrease in the maize cob length was obtained with RP rates mixed with PL, reaching $9 \%$ with a major $\mathrm{RP}$ rate of $9 \mathrm{Mg} \mathrm{ha}^{-1}$ jointly applied with $8 \mathrm{Mg} \mathrm{ha}^{-1}$ of PL (Figure 4A). Rows per cob (Figure 4B) and grain yields (Figure 4C) responded in a quadratic manner to the RP doses mixed with the poultry litter, resulting in doses of the maximum technical efficiency of 5.6 and $4.1 \mathrm{Mg} \mathrm{ha}^{-1}$, respectively.

Again, there was confirmation of the existence of a synergistic interaction between fresh $\mathrm{PL}$ and $\mathrm{RP}$, in terms of cob length, rows per cob and grain yield (Figure $4 \mathrm{~A}-\mathrm{C})$. The decrease in cob length in maize grains crops with RP doses within PL fixed dose (Figure 4A) was antagonistic to the quadratic effects in rows per cob and grain yields, providing a maximum increase in the number of rows per cob (Figure 4B) and grain yields (Figure $4 \mathrm{C}$ ) up to 5.6 and $4.1 \mathrm{Mg} \mathrm{ha}^{-1}$ of $\mathrm{RP}$, respectively.

An eventual initial effect of fluorine on the reduction of cob length may have been alleviated by $\mathrm{P}$ and $\mathrm{N}$ assimilation in the later stages of the definition of maize rows and grain filling.

\section{Conclusion}

Application of a combination of poultry litter and rock phosphate reduces soil organic $\mathrm{C}$, while rock phosphate alone increases the humin fraction $\mathrm{C}$ compared to the control. The microbial biomass $\mathrm{C}$ in soil with both poultry litter and the combination of poultry litter and rock phosphate and P-solubilizing microorganisms was higher than in both the control and the rock phosphate treatments. Inoculation of poultry litter and rock phosphate with P-solubilizing microorganisms does not alter soil organic matter pools and whole-plant silage or grain yields of maize crop. The best ratio combination of poultry litter to rock phosphate is $2: 1$, in the anticipated fall application on the maize silage or immediate application on the maize grain crops. This synergistic interaction in the application of poultry litter with rock phosphate adds positive technical aspects to the advantage of reducing operational costs and time of application for agroecological agribusiness, in anticipated fall application to maize silage crop or immediate application to maize grain crops.
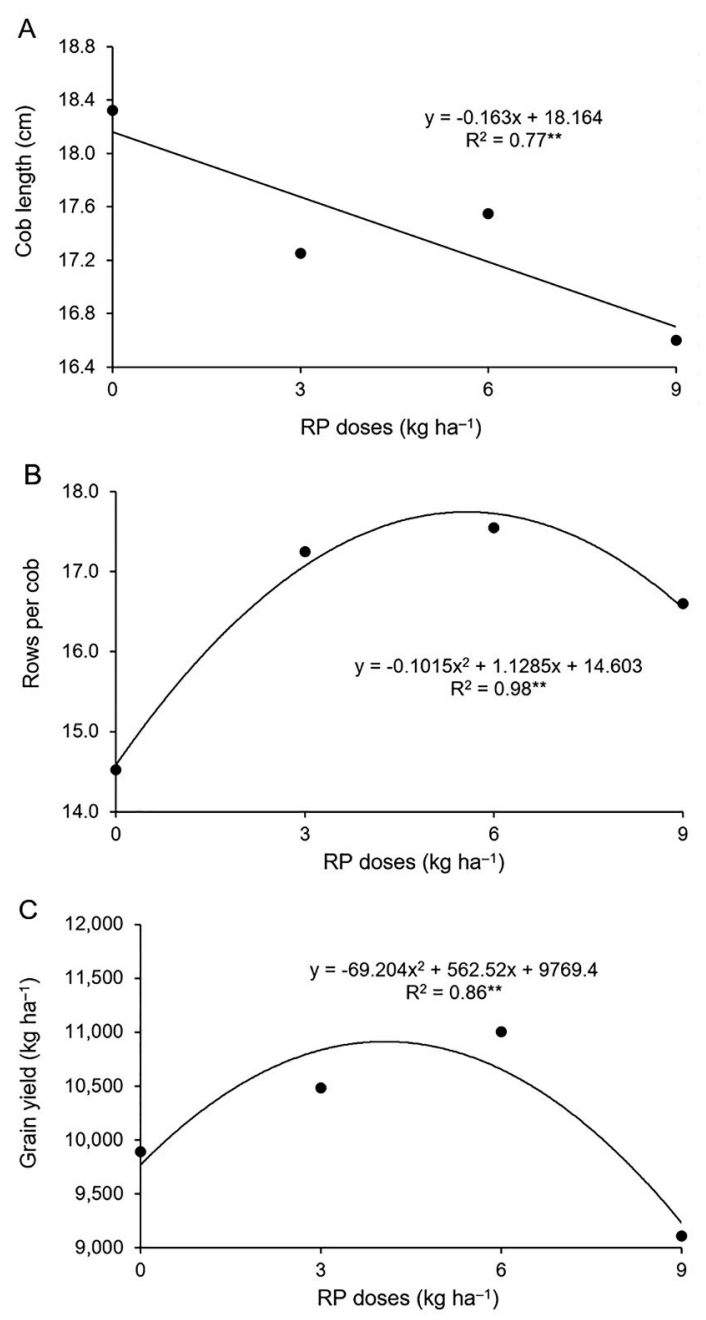

Figure 4 - Cob lengths A), rows per cob B) and grain yields C) of maize grain crop as a function of rock phosphate (RP) doses mixed with poultry litter. ${ }^{*}$ significant at $1 \%$ probability.

\section{Acknowledgments}

TCFQ and BHM acknowledge MSc. and post-doctoral scholarship, respectively, from the Coordenação de Aperfeiçoamento de Pessoal de Nível Superior (CAPES). This study was partially supported by the Conselho Nacional de Desenvolvimento Científico e Tecnológico (CNPq) Project INCT-CNPq, MPCPAgro $465133 / 2014-2)$. DSA is also a research fellow of CNPq (312996/2017-9).

\section{Authors' Contributions}

Conceptualization: Yagi, R.; Quadros, T.C.F.; Andrade, D.S. Data acquisition: Yagi, R.; Quadros, T.C.F.; Martins, B.H. Design of Methodology: Yagi, R.; Quadros, T.C.F.; Martins, B.H.; Andrade, D.S. Writing and editing: Yagi, R.; Quadros, T.C.F.; Martins, B. H.; Andrade, D.S. 


\section{References}

Abbasi, M.; Musa, N.; Manzoor, M. 2015. Phosphorus release capacity of soluble $\mathrm{P}$ fertilizers and insoluble rock phosphate in response to phosphate solubilizing bacteria and poultry manure and their effect on plant growth promotion and $\mathrm{P}$ utilization efficiency of chilli (Capsicum annuum L.). Biogeosciences Discussion 12: 1839-1873.

Abbasi, M.K.; Mansha, S.; Rahim, N.; Ali, A. 2013. Agronomic effectiveness and phosphorus utilization efficiency of rock phosphate applied to winter wheat. Agronomy Journal 105: 1606-1612.

Abbasi, M.K.; Manzoor, M. 2018. Biosolubilization of phosphorus from rock phosphate and other $\mathrm{P}$ fertilizers in response to phosphate solubilizing bacteria and poultry manure in a silt loam calcareous soil. Journal of Plant Nutrition and Soil Science 181: 345-356.

Agyarko, K.; Abunyewa, A.A.; Asiedu, E.K.; Heva, E. 2016. Dissolution of rock phosphate in animal manure soil amendment and lettuce growth. Eurasian Journal of Soil Science 5: 84-88.

Ahmed, O.H.; Rosliza, S.; Majid, N.M.A.; Jalloh, M.B. 2012. Effect of $\mathrm{N}, \mathrm{P}$ and $\mathrm{K}$ humates on dry matter of Zea mays and soil $\mathrm{pH}$, exchangeable ammonium and available nitrate. African Journal of Biotechnology 11: 9566-9571.

Ali, A.; Sharif, M.; Wahid, F.; Zhang, Z.; Shah S N, M.; Rafiullah, Z.S.; Khan, F.; Rehman, F. 2014. Effect of composted rock phosphate with organic materials on yield and phosphorus uptake of berseem and maize. American Journal of Plant Sciences 5: 975-984.

Alvares, C.A.; Stape, J.L.; Sentelhas, P.C.; Gonçalves, J.L.M.; Sparovek, G. 2013. Köppen's climate classification map for Brazil. Meteorologische Zeitschrift 22: 711-728.

Baveye, P.C. 2015. Looming scarcity of phosphate rock and intensification of soil phosphorus research. Revista Brasileira de Ciência do Solo 39: 637-642.

Billah, M.; Bano, A. 2015. Role of plant growth promoting rhizobacteria in modulating the efficiency of poultry litter composting with rock phosphate and its effect on growth and yield of wheat. Waste Management and Research 33: 63-72.

Biswas, D.; Narayanasamy, G. 2006. Rock phosphate enriched compost: an approach to improve low-grade Indian rock phosphate. Bioresource Technology 97: 2243-2251.

Bolan, N.; Elliott, J.; Gregg, P.; Weil, S. 1997. Enhanced dissolution of phosphate rocks in the rhizosphere. Biology and Fertility of Soils 24: 169-174.

Dorozhkin, S.V. 1997. Surface reactions of apatite dissolution. Journal of Colloid and Interface Science 191: 489-497.

de Goes, K.C.G.P.; da Silva, J.J.; Lovato, G.M.; Iamanaka, B.T.; Massi, F.P.; Andrade, D.S. 2017. Talaromyces sayulitensis, Acidiella bohemica and Penicillium citrinum in Brazilian oil shale by-products. Antonie van Leeuwenhoek 110: 1637-1646.

Empresa Brasileira de Pesquisa Agropecuária [EMBRAPA]. 1997. Manual of Soil Analysis Methods. = Manual de Métodos de Análise de Solos. 2ed. Embrapa-Centro Nacional de Pesquisa do Solo, Rio de Janeiro, RJ, Brazil (in Portuguese).
Feng, G.; Tewolde, H.; Ma, L.; Adeli, A.; Sistani, K.R.; Jenkins, J.N. 2015. Simulating the fate of fall- and spring-applied poultry litter nitrogen in corn production. Soil Science Society of America Journal 79: 1804-1814.

Foloni, J.S.S.; Tiritan, C.S.; Calonego, J.C.; Alves Junior, J. 2008. Rock phosphate fertilization and phosphorus recycling by pearl millet, Brachiaria sp., corn and soybean. Aplicação de fosfato natural e reciclagem de fósforo por milheto, braquiária, milho e soja. Revista Brasileira de Ciência do Solo 32: 1147-1155 (in Portuguese).

George, T.S.; Hinsinger, P.; Turner, B.L. 2016. Phosphorus in soils and plants: facing phosphorus scarcity. Plant and Soil 401: 1-6.

Giro, V.; Jindo, K.; Vittorazzi, R.; Conceição, G.; Canellas, L.; Olivares, F. 2016. Rock phosphate combined with phosphatesolubilizing microorganisms and humic substance for reduction of plant phosphorus demands from single superphosphate. Acta Horticulturae 1146: 63-68.

Herrera-Estrella, L.; López-Arredondo, D. 2016. Phosphorus: the underrated element for feeding the world. Trends in Plant Science 21: 461-463.

Khan, M.; Sharif, M. 2012. Solubility enhancement of phosphorus from rock phosphate through composting with poultry litter. Sarhad Journal of Agriculture 28: 415-420.

Kuwano, B.H.; Nogueira, M.A.; Santos, C.A.; Fagotti, D.S.L.; Santos, M.B.; Lescano, L.E.A.M.; Andrade, D.S.; Barbosa, G.M.C.; Tavares-Filho, J. 2016. Application of landfill leachate improves wheat nutrition and yield but has minor effects on soil properties. Journal of Environmental Quality 46: 153-159.

Kuzyakov, Y. 2002. Factors affecting rhizosphere priming effects. Journal of Plant Nutrition and Soil Science 165: 382-396.

Lin, Y.; Watts, D.B.; Kloepper, J.W.; Torbert, H.A. 2018. Influence of plant growth-promoting rhizobacteria on corn growth under different fertility sources. Communications in Soil Science and Plant Analysis 49: 1239-1255.

Mahimairaja, S.; Bolan, N.; Hedley, M. 1995. Agronomic effectiveness of poultry manure composts. Communications in Soil Science and Plant Analysis 26: 1843-1861.

Mendes, G.O.; Vassilev, N.B.; Bonduki, V.H.A.; Silva, I.R.; Ribeiro Junior, J.I.; Costa, M.D. 2013. Inhibition of Aspergillus niger phosphate solubilization by fluoride released from rock phosphate. Applied Environmental and Microbiology 79: 49064913.

Mierzwa-Hersztek, M.; Klimkowicz-Pawlas, A.; Gondek, K. 2017. Influence of poultry litter and poultry litter biochar on soil microbial respiration and nitrifying bacteria activity. Waste and Biomass Valorization 9: 379-389.

Miyazawa, M.; Pavan, M.A.; Muraoka, T.; Carmo, C.A.F.S.D.; Melo, W.J.D. 2009. p. 193-233. Chemical analysis of plant tissue. = Análise química de tecido vegetal. In: Silva, F.C., ed. Manual of chemical analyses of soils, plants and fertilizers. = Manual de análises químicas de solos, plantas e fertilizantes. Embrapa-Informação Tecnológica, Brasília, DF, Brazil (in Portuguese).

Murphy, E.M.; Zachara, J.M.; Smith, S.C. 1990. Influence of mineral-bound humic substances on the sorption of hydrophobic organic compounds. Environmental Science \& Technology 24: 1507-1516. 
Panchoni, L.C.; Santos, C.A.; Kuwano, B.H.; Carmo, K.B.; Cely, M.V.T.; Oliveira-Júnior, A.G.; Fagotti, D.S.L.; Cervantes, V.N.M.; Zangaro, W.; Andrade, D.S.; Andrade, G.; Nogueira, M.A. 2016. Effect of landfill leachate on cereal nutrition and productivity and on soil properties. Journal of Environmental Quality 45: 1080-1086.

Pavan, M.A.; Bloch, M.F.D.; Zempulski, H.C.D.; Miyazawa, M.; Zocoler, D.C. 1992. Manual of soil chemical analysis and quality control. $=$ Manual de análise química de solo e controle de qualidade. Instituto Agronômico do Paraná, Londrina, PR, Brazil (in Portuguese).

Rippka, R.; Deruelles, J.; Waterbury, J.B.; Herdman, M.; Stanier, R.Y. 1979. Generic assignments, strain histories and properties of pure cultures of cyanobacteria. Journal of General Microbiology 111: 1-61.

Rogeri, D.A.; Ernani, P.R.; Mantovani, A.; Lourenço, K.S. 2016. Composition of poultry litter in southern Brazil. Revista Brasileira de Ciência do Solo 40: e0140697.

Sanni, K.O.; Ewulo, B.S. 2015. Effects of phosphorus and organic fertilizers on the yield and proximate nutrient composition of lettuce (Lactuca sativa) in southwestern Nigeria. International Journal of Horticulture 5: 1-7.
Silva, J.O.; Franceschini, S.A.; Lavrador, M.A.S.; Candido, R.C. 2004. Performance of selective and differential media in the primary isolation of yeasts from different biological samples. Mycopathologia 157: 29-36.

Soil Survey Staff. 2014. Keys to Soil Taxonomy. 12ed. USDANRCS, Washington, DC, USA.

Swift, R.S. 1996. p. 1018-1020. Organic matter characterization. In: D.L. Sparks, ed. Methods of soil analysis. Part 3. Chemical methods. Soil Sci. Soc. Am. Book Series: 5. Soil Sci. Soc. Am. Madison, Wisconsin, USA.

Tewolde, H.; Sistani, K.R.; Adeli, A. 2013. Fall- and spring-applied poultry litter effectiveness as corn fertilizer in the mid-southern United States. Agronomy Journal 105: 1743-1748.

Vance, E.D.; Brookes, P.C.; Jenkinson, D.S. 1987. An extraction method for measuring soil microbial biomass C. Soil Biology and Biochemistry 19: 703-707.

Vincent, J. 1970. A Manual for the Practical Study of Root Nodule Bacteria. Blackwell Scientific, Oxford, UK.

Walkley, A.; Black, I.A. 1934. An examination of the Degtjareff method for determining soil organic matter, and a proposed modification of the chromic acid titration method. Soil Science 37: 29-38. 